This item was submitted to Loughborough's Research Repository by the author.

Items in Figshare are protected by copyright, with all rights reserved, unless otherwise indicated.

\title{
Confucianism and democratization in East Asia
}

PLEASE CITE THE PUBLISHED VERSION

http://www.pacificaffairs.ubc.ca/recent-issues/recent-issue-vol-86-no-2-june-2013/

\section{PUBLISHER}

The University of British Columbia

\section{VERSION}

SMUR (Submitted Manuscript Under Review)

\section{PUBLISHER STATEMENT}

This work is made available according to the conditions of the Creative Commons Attribution-NonCommercialNoDerivatives 4.0 International (CC BY-NC-ND 4.0) licence. Full details of this licence are available at: https://creativecommons.org/licenses/by-nc-nd/4.0/

\section{LICENCE}

CC BY-NC-ND 4.0

\section{REPOSITORY RECORD}

Tamaki, Taku. 2019. "Confucianism and Democratization in East Asia". figshare. https://hdl.handle.net/2134/15866. 
CONFUCIANISM AND DEMOCRATIZATION IN EAST ASIA. By Do Chull Shin. Cambridge; New York: Cambridge University Press, 2012. X, 366 pp. (Tables, figures) US\$28.99, paper. ISBN 978-1-107-63178-6.

This book provides another welcome addition to the study of Confucianism, and its relevance to the understanding of social- and political cultures in contemporary East Asia. Do Chull Shin engages with the philosophical underpinnings of Confucianism—along with the ideas and words attributed to Confucius himself-to determine whether "East Asia is a region infused with the core values of Confucianism" (p. 3). The author embarks on an analysis of whether Confucianism, as a system of ethics and a system of political ethics (p. 8), is compatible with the patterns of democratization we observe in the region. As such, Shin's project is ambitious, as it is revealing.

The author's main question seems to be to "resolve [the debate whether Confucian traditions are compatible with democracy] empirically by analyzing how Confucian political and social norms encourage or discourage the mass citizenries of historically Confucian Asia from becoming members of a civil community and citizens of a democratic state” (p. 5). Hence, the book entails revisiting the philosophical underpinnings of Confucianism by debunking some of the misunderstandings, such as the temptation to focus on its authoritarian, rather than normative, dimensions; as well as providing a wealth of data sets to fathom contemporary public opinion on various aspects of governance and legitimacy across several East Asian societies. In this respect, the book provides an interesting juxtaposition of theory and empirical findings. On the one hand, Shin provides an intriguing set of arguments to engage wholeheartedly with the intricacies of Confucian thinking into authority and legitimacy in governance. On the other hand, the author embarks on an ambitious project to determine whether Confucian ideas are shared by the populace in Confucian East Asia, however construed. The challenge seems to be whether or not the two discernible parts are well integrated to provide a coherent set of narratives that enhance our appreciation of Confucian legacies in East Asia today.

Shin's discussions into the historical development of Confucianism-as 
opposed to, and sometimes in opposition to, the ideas and words attributed to Confucius-is the strongest part of this book. The author successfully dispels the notion that Confucianism equals authoritarianism by successfully arguing that the Confucian notions of power, authority, and legitimacy are social, as well as political, concepts. This means that Confucianism assumes a two-way street involving authority that flows from the ruler to the subjects, on the one hand; and legitimacy that flows in the opposite direction, on the other. As such, despite the temptation to focus solely on the authoritarian tendencies seen in several parts of East Asia, Shin shows that Confucianism is concerned about virtue, justice, and responsibility are crucial ingredients to successful governance. The author notes that Confucian political ethics and doctrine support hybrid systems "when integrated with the procedural form of democracy” (p. 70). Hence, Shin's theoretical contribution constitutes a welcome addition to the current debates on Confucianism and democratization.

However, these theoretical arguments seem to encounter "translation” problems once the discussion moves onto empirical findings. Put differently, there are questions as to how the philosophical dimensions of Confucianism "translate" to contemporary East Asian public opinion.

Shin's identification of Confucian legacies_-the Family; the State; Schools; and Patterns of Thinking and Behaving (pp. 40ff) - is well-taken. However, there is also a sense of overdetermination: while these legacies might constitute familiar indicators of Confucianism, more needs to be said about how relevant these legacies are to East Asian societies under review. In a similar vein, a further elaboration is needed to delineate Confucian- and non-Confucian Asian societies (pp. 9-10). This is particularly important, as the proponents of Asian Values, who draw legitimacy from Confucianism, span both Confucian- and non-Confucian East Asia using Shin's typology. Moreover, there is an impression that the correlation that seems to exist between the various notions of legitimacy and authority is frequently used as a "proof" of causation. Put differently, without further analyses into the role played by political cultures and particular historical trajectories of individual, "Confucian,” Asian societies, it remains questionable whether claims to causation can be firmly established. To be sure, the author does not explicitly conflate correlation with causation; yet, there are several claims to the existence of a "proof" of a relationship between Confucian tradition and 
public opinion (pp. 157; 214; 299).

The author's conclusion that Confucian political legacy offsets "liberalizing efforts of socioeconomic modernization on cultural democratization” (p. 323); and that effects of Confucian social legacy seem inconclusive (ibid.) are reasonable. Shin provides plausible counterarguments to the charges of overgeneralization. He argues that, "[i]n historically Confucian East Asia today, popular attachment to Confucianism is miles wide but only inches deep" (p. 320), and that the "people are less attached to Confucianism as a model of conduct or way of life than as a source for politics or a system of government” (ibid.), especially in recognizing that “[h]istorically Confucian East Asia is no longer a single cultural zone in regard to the mass public's commitment to the legacies of Confucian social and political ethics” (ibid.). He also claims that none of these factors are unique to Confucian East Asia, per se (p. 321). Shin also provides a useful critique of Asian Values discourse (pp. 330-31); but the sense of overgeneralization remains, stating that, "[i]n Confucian Asia, people are exposed to Confucianism as a way of life from early childhood” (p. 331)—again without adequate analyses into the particular political- and historical experiences of individual East Asian societies.

Overall, the theoretical exploration is very well laid out: this part constitutes the strongest element of this book as another in-depth analysis that is crucial to the better appreciation of Confucian political philosophy. Once the "translation" problem, along with the lingering sense of overgeneralization, is addressed, the strengths of this book should stand out even more. Having said this, the empirical findings are quite revealing on their own. As such, this book provides a welcome intervention into the debates on the relevance of Confucianism in understanding contemporary East Asian society. 